\title{
Acts and Actors: Decolonising the Study of Architecture at a South African University
}

\section{Juan Ignacio Solis-Arias \\ ORCID ID: https://orcid.org/0000-0001-9516-1525}

\begin{abstract}
In this article, I examine the practices of coloniality and ethnic African liberalism within the South African university where I teach. I do this by examining how Black and ethnic Zulu students were treated by examiners from East Africa. I examine some of the prominent features of colonisation and its recycling at the hands of the colonised who transfer and re-enact coloniality upon a younger generation of newcomers who have recently entered an ageold discipline, delayed by the racialised policies and practices of the apartheid regime. In doing so, I bring forth the history of my racialisation whilst offering a possibility for where and how a decolonial approach might be necessary to move both the curriculum and pedagogical approach of the School of Architecture at the University of KwaZulu-Natal forward, and the agenda of the university with regards to its Transformation Charter, particularly its current focus on decolonising the curriculum.
\end{abstract}

Keywords: South African Architecture curriculum, African liberalism, decoloniality, intermalised coloniality

\section{Introduction}

This article, examines the practices of coloniality and ethnic African liberalism within the South African university where I teach. I do this by examining how Black and ethnic Zulu students were treated by examiners from East Africa. I examine some of the prominent features of colonisation and its recycling at the hands of the colonised who transfer and re-enact coloniality upon a younger generation of newcomers who have entered an age-old discipline due to the racialised policies and practices of the apartheid regime. In doing so, I bring forth the history of my racialisation whilst offering a possibility for where and 
how a decolonial approach might be necessary to move both the curriculum and pedagogical approach of the School of Architecture at the University of KwaZulu-Natal (UKZN) forward, and the agenda of the university with regards to its Transformation Charter, particularly its current focus on decolonising the curriculum.

Before 1994, Architecture as a discipline of study within the South African university system was taught within White dominated universities for the sole purpose of ensuring that White South Africans would be involved in all aspects of the apartheid process: its education, structuring, building and implementation (Kallaway 2002). As the term apartheid suggests - apart, separate, apartness - the usurpation, theft and subsequent allocation of land, distributed among the settler community were undertaken by the settler, then apartheid government and the built environment was created by town planners, engineers and architects, trained during this period to ensure that 'the city' and its pockets, townships, homelands, and land from which Indigenous people were forcibly removed, were all aligned with the apartheid policies that facilitated and enabled the system of White domination and Black subjugation (O’Connell 2014). As Belinda Dodson (2013) argues, this situation is parallel to the situation of spaces within our cities are still reflecting apartheid planning, which we see daily along with its social, political and psychological legacy. Apartheid left physically built forms, spatial divisions, and landscape scars that, unlike apartheid laws, could not simply be undone at the stroke of a 'presidential pen' (Dobson 2013: 1). Similarly, attitudes of White privilege and entitlement among White colleagues tend to go unchallenged as the system itself has not changed much. Even though there was a change in government, the state and its governance did not necessarily change. A new constitution heralded a process of breaking with apartheid laws, yet the realities are still evident within the system that does not challenge White attitudes especially within Architecture where White colleagues believe they have ownership.

During the apartheid years, architects - much like engineers and townplanners - came from the White population, where their early, secondary, and higher education was set on furthering their White dominance, and simultaneously allowing their governance over the oppressed and the colonised communities of South Africa. The amount of money the apartheid regime spent on a White child, an Indian child, a Coloured child, then a Black child, in that order of bottom-up hierarchy, offers us further insight into how this stratification within basic and further education fostered the material 
conditions for inequality and allowed the White population to continue to benefit from governance, dominance, and control (Netswera \& Mathaba 2006). White universities catered to the needs of the apartheid regimes' grand plan of segregation by participating in the design and planning of the aftermath of usurpation and settler colonialism, and as such, White students who became architects under these conditions (Coetzer 2016) assumed their 'rightful place' within the society that they lived, and into the post-1994 South Africa with the firm belief that architecture was their domain, their rightful place as leaders, teachers and gatekeepers of the country, particularly the built environment, and ultimately the conditions under which Black students had to learn.

In this article:

1. I locate my point of departure as a foreigner in South Africa, using an existential approach to bring forth my racialisation, and situate my presence within the School of Architecture where I teach;

2. I unpack how examiners from East African countries enter the university, which is located in KwaZulu-Natal Province, South Africa, which was a previously Whites-only university; and

3. I examine the curriculum, which continues to be European-based, for a student population where more than $90 \%$ of the learners are Black that is, of African, Indian South African, and Coloured heritage.

\section{Methods and Approaches: Autoethnography, Existentialism and Critical Race Theory}

My point of entry into this article is as a foreigner from Colombia to South Africa. I married a Black South African woman more than three decades ago and moved to South Africa, when it became clear that she wanted to be back in her home country permanently after the formal end of apartheid in 1994. I raise this for reasons which speak to her politicised identity and not mine in her racialised context of South Africa, and for reasons that we each steer clear from, such as depictions of coupledom and heteronormativity. Instead, I wish to put forward my existentialist framework for this article in offering my reflections on how I came to understand my racialised identity. As a man who 
was born in Colombia, I was classified as both Mestizo, which is a racialised identity of Indigenous and Spanish descent, and trigeño, which is a pigmented identity. Columbus' 'discovery' of the Americas has led to the continued use of the term, 'American Indian' when referring to Indigenous peoples of the Americas. And whilst Colombians still today take a certain pride in the classification of Mestizo, through which we (I intentionally refrain from the use of the word they as I consider my upbringing implicated in the very process that I critique) are also able to falsely claim that we are of European descent, and therefore White or 'almost White' (an expression I return to later in this article).

These racialised identities were created so that there would be a population that identified with the coloniser on the one hand, and against the African enslaved and Indigenous population on the other. Besides, I am acutely aware that among people who self-identify, the term Black in Colombia is used sparingly, and with trepidation. Similarly, the term Afro-Colombian, the preferred term, is also used with caution and only offered by the person who self-identifies. In Spanish, the word negro refers both to the colour black (as in the colour of a shoe, for example) and to the person who carries African heritage. The latter is often used as a diminutive, as in el negrito (the little Black person) as a term of debasement towards the person upon which it is inflicted, Mestizo Colombians insist that the term is one of endearment. When asked whether the speaker would object if the term was bestowed upon him or her, such speaker would often say, 'I don't mind ... but I am not Black'.

Racialised identities remain a complex expression that leans towards identifying oneself, and the person to whom one is referring, with terms that offer them the Whitest (in terms of racialised identity) possible description. The naming of negrito is considered an etiquette, and an act of kindness; the practice of inaccurately offering a false identity is considered an expression of goodwill, and for which the speaker is rewarded. To clarify, the term negrito is conditioned as a label associated with someone who has darker skin, regardless of their heritage and ethnicity. The Mestizo identity, by definition, is not only inaccurate if one examines the DNA make-up of the alleged Mestizo population of Colombia but it foregrounds European-ness in such a way that the number of European colonisers in Colombia is exaggerated. Additionally, and more critical, the Indigenous peoples are shifted to the borders of the unconscious, made invisible, placed in the 'jungles' so that as Colombians we can feel good about ourselves because we are far removed from the Indigenous 
people from whom we owe our existence. Colombians refuse to grapple with indigeneity, our Indigeneity, and whole-heartedly believe, for the most part, that our Indigenous ancestry is either non-existent or of such a small percentage that it is not worth mentioning. Better still, those who identify as Mestizo stand firm in their belief, particularly after their 'nose jobs' and dyed blonde hair, which of course are courtesy of the many plastic surgeons our country continues to produce, and the peroxide infused hair products Revlon and similar companies has manufactured over the years to maintain the false consciousness of blanqueamiento (Ministerio de Educacion Nacional 2011), which is the active process of trying to make oneself appear White and as 'European-looking' as possible.

The term trigeño takes its name from wheat; trigo, means wheat in Spanish, and therefore suggests a skin colour that resembles the colour of wheat. For reasons that speak to the length and focus of this article, let me say, in brief, that my history as someone who comes from the Indigenous people of South America has consistently been denied in my family - both on my mother's and my father's sides. Not only did this become an embarrassment to me in my early twenties but also to the many people from similar backgrounds in Colombia I met, especially during my university education in Bogotá, who dutifully performed this customary denial, even though our facial features, much like mine, spoke directly to our Indigenous heritage. The fact that I, like my father, am lighter in skin colour than the rest of my family members speaks directly to Indigenous ancestry that emanates from the colder mountainous regions rather than the warm coastal areas.

When I studied in the United Kingdom (UK), I met people who were from South America who were ignorant of the skin colour identities of Indigenous peoples and called themselves White. As soon as we met Spanish students from the empire, the humiliation and ridicule, the condescension, and the patronising attitude of our presence as 'little Indians' soon changed the mindset of the South American students with whom I kept company. We were, instantly, all at once, the Indigenous people of the Americas and reduced to an existential nothingness, 'Los Indios' by our colonisers. In the many verbal declarations that followed, I observed their defence with amusement as I noted the immediate embrace of Indigeneity by my South American peers. This act of claiming Indigeneity made me acutely aware that my peers' identity politics were not grounded in ignorance as I previously thought, but in a desire to assert governance that speaks to social class, first and foremost. This was coupled 
with racialisation, as long as the conquistadores [colonisers] were not in the room to remind us that we were the wretched, 'savage' Indians whom they saved with Catholicism and whom they robbed of gold and emeralds while we 'allowed' them to. My Masters' degree supervisor at the time at the University of York, when introducing me to the students he supervised referred to me and another South American student as 'exotic', to which I hastily replied that I was not a plant or bird of the forest. He seemed rather shocked at the immediacy of my response, as he had, in his description of me, constructed me as a quiet, well-mannered Latino.

But let me return to my home and my upbringing: My paternal grandfather, for example, is visibly Black - I did not need anyone to point this out to me as a child and yet it remains an unspoken topic within the vast repertoire of annual gatherings were elders speak to the younger generation of their youth, significant events in their life when they were growing up, and events that allow us as the younger generation to learn from them. Yet, our racialised identity is hardly spoken about nor is there an open and agreed acceptance of our ancestral heritage, which is Indigenous, as is evidenced by my facial features, that of my daughter's, my siblings and their children, and many members of our family - most of whom would shudder, let alone be insulted, at the knowledge that I have identified them in this manner. Indigeneity is worn as a mark of shame, a topic for jokes and a basis for reprimand with the intent to ridicule. Twenty-first century children are still encouraged to say, 'Los Indios' about people who live in the Amazonas, and when calling out behaviour that is contrary to the norm of a presumed middle and upper class, that are then labelled unmannerly, rude, uncouth, lacking in sophistication, to which the added expression that contains the word muy, as in 'very', muy Indio is used to silence the person into shame, and remind them that they have not successfully rid themselves of their unfortunate ancestry.

When I was a teenager, my paternal uncle, my father's second brother, who worked as a pilot, took me under his wing for a short time. He invited me to join him on a trip to the United States of America (USA) shortly after my 17 th birthday, as a means of getting to know me and to persuade me to study architecture in the USA. He was very different from my father, who is a businessman, considered rather quiet, stern, a disciplinarian, strict and someone who does not consider his sons as his friends. My uncle, on the other hand, had one daughter and three sons and would go on hiking trips with his sons. During my time with my uncle he shared with me how as the second 
oldest child, and second oldest son, he was called 'el negrito' which, as previously mentioned, in the Colombian context means 'the little black'. Unlike in the USA, the term 'el negro' is not given the same historical significance in Colombia nor the politicised significance of the 'n-word', which bears many levels of racial tropes around the world especially among those who understand the triggering effect of the word, its history of enslavement of the African people across the Atlantic, the histories of lynching, murder, rape and massacres.

My uncle was called 'el negrito' and 'el Negro' because his Black heritage was visible; he was, as it were, 'the black one' in his family. As the second child, and second son, he was also visibly darker than my father, and because my paternal grandmother could not hide her son's obviously Black heritage, she hid him! My uncle was put in another room, and out of sight of visitors, at times closed in a cupboard, even though he resembled my father quite a lot, and started to resemble all of his siblings born after him, all of whom were lighter in skin colour. He shared this history of his childhood with me, with great detail, and with anguish on his face and tenseness in his body. It was clear to me in his narration that the pain that was inflicted was deep. As I grew from the teenager he shared these stories with into a man I saw his pain manifest itself in many different ways, one of which included always expecting someone to demean him, for which he readily had a response waiting.

During my teens, as I grew into understanding what these identities meant, I learnt that in my society it was far more shameful to be descended from 'Los Indios' than it was from 'Los Negros' since the latter afforded us as Latinos a sexiness, a rhythm in our dance and a love for pleasure that our Spanish colonisers could never erase, despite their attempts. The 'Los Indios' part of my identity I had to carry with shame because this heritage placed me in the inevitable predicament of being a carrier of a series of traits stereotypically inflicted by our Spanish colonisers to depict our inhumanity, as such the justification for our colonisation: unintelligent, a 'savage', without grace, violent, no Western etiquette or desire for a code of behaviour that placed me among humans, and therefore undesirable to count as not only part of my DNA but as the main contributor to my DNA.

My decolonisation is not a process I can fully offer an account of here; this is an ongoing process that continually demands taking responsibility for my thinking and undoing the processes I was taught to uphold, along with the values and beliefs of my colonisers. But it was not only the history of my uncle 
that broke the silence of racial abuse I suspected, it was also the actions of the wife of one of his sons who openly announced a few years ago that her darkskinned children did not get their skin colour from her side of the family but from their father's side. She wanted to make a point - that there were "no Blacks' on her side of the family even though the oblivion and contempt she held for her own dark skin was obvious, to which the necessary etiquette of the moment allowed me a silent, mindful awareness . . . perhaps even a grimace. I stood in amazement, reflecting on what my uncle had shared with me. The children of my cousin were now being ridiculed by their mother for being darker than her side of the family; she did not hesitate to call them into the house for fear that the sun might further deepen their Blackness.

\section{Colonisation and the Transatlantic Effect}

In addressing decolonisation in a context outside of my birth I am very much aware that this process transcends oceans. If one addresses oneself in the context one finds oneself in and understands the history of ones' location and your place within it, one notices a pattern, a repetition of racism and colonisation, of internalised racism and divide and conquer strategies, and the accompanying tactics. I traced this trajectory to offer an account of my decolonial journey, and as a father to a daughter of Indigenous African and Indigenous Colombian heritage, whose birth and racialisation in Canada and Colombia, opened my eyes to a reality that forged a particular agency within me, I decided many years ago that I had no right to claim silence as a defence mechanism because it suited my quiet disposition; the latter was always put forward as a great compliment that I as a Latino man carried and of which I needed to feel proud. It is only in the past 28 years that I began to speak out, and not silently sit by and observe the many and multi-layered processes of racism, internalised racism and colonisation unfold in my presence. On many occasions, I caught myself being the good, well-mannered Latino, whose light skin placed me outside of the realm of confrontation if I so chose. I felt the eyes of the perpetrators on me in ways that confirmed that they knew something about me: that not only had I been shielded by my lighter skin than the Black people or Indigenous people they ridiculed - and of which I was expected to understand that I was excluded - but on occasion when I wanted to address the said matter I did not have the language to confront these perpetrators. The regular doses of Catholic guilt with which the matter forged 
a stronghold in my life - through childhood in a Catholic home, school and broader society - did not equip me to challenge family members, friends or older relatives against whom one's confrontation would be treated as an act of disrespect. Speaking out against racism and coloniality has since then become part of my life as a choice; silence is no longer an option, as the birth of my daughter 28 years ago disrupted that possibility forever. As such, in this article: in offering a narrative of my education on race, some of which includes the way that Blackness and degrees of Blackness operated and continue to operate in my background, my concern has been with ways in which the subject of the racialised experience develops an awareness of her/his lived conditions and understands the implications of its reproduction. If and when we speak of decolonisation, are our histories left in the geographical spaces of our birth or do they, like us, travel and meander within the globe, where we engage with the world and continue our commitment to deracialise and decolonise ourselves in geographical spaces where the meaning of our racialisation takes on new and different nuances?

\section{Joining the University of KwaZulu-Natal's School of Architecture}

In September 2011, I joined the Architecture discipline at UKZN. With a fiveyear degree from Universidad del Javeriana in Bogotá, Colombia, a Masters' degree from the University of York in the UK, several years of private practice on diverse projects, mentorship of younger architects I was able to bring my expertise to UKZN. As a design lecturer, fully aware of my foreigner status, I began to immerse myself within the school's broad range of teaching and learning activities rather quickly. I was pleased that I could draw on my history of community architecture, especially my earlier work on the participation of residents in community architecture projects in Colombia and share some of those experiences with our Masters students.

\section{My First Internal Examiner Experience at UKZN}

In December of 2011, I was asked to be an internal examiner for the Masters' design project's portfolios (a two-year degree); these are students who are in the fifth year of their study, hence the final year of their Masters' degree. We were 10 internal examiners from UKZN and seven external examiners from 
various South African universities as well as three examiners from East Africa, Later, within conversation, I ascertained that two were from Kenya and one from Uganda, thus amounting to a total of 20 examiners.

The process was that each of us offered a comment, a verbal and written opinion of the work exhibited, and allocated an individual mark to each of the students' presentations and their exhibited projects. As per the process, we were then asked to offer our analysis and overall evaluation of each of the projects. It is by no means a surprise to find, like in all professions, that opinions among architects differ. Opinions that we draw on are, as such, from our education and training, how the latter was cultivated. Like all professions, architects also cultivate certain likes and dislikes, and these are often voiced between and among one another regularly in a professional setting, not in the company of students over whom we preside as examiners. As such, one examiner would comment on certain aspects of what they saw while another would reflect on something very different within the same student's project. The grade average from all examiners then determines the final mark of the student's project.

On the day in question, we had a group of students with different racial backgrounds, indicative of the KwaZulu-Natal landscape whose work we had to examine: Black, Indian, Coloured and White. It has to be noted that the Zulu population group, also noted as an ethnic group constitutes the vast majority in the province, and likewise within UKZN. What became clear during the students' presentation, a process that was headed by the fifth-year coordinator who self-identified as a French-speaking West African national. Each time a Black student was introduced to the examiners, it was done with offensive, derogatory and humiliating off-the-cuff comments upon the revelation of the student's name and identity, which involved pointing to and/or physical identification so that all examiners could see who the student was. The coordinator took these liberties, openly, with a great degree of entitlement, and no one stopped him. It was my first time as an examiner at UKZN and whilst I knew that it could not possibly be part of the formal procedure, I sought disapproving verbal and facial expressions from my peers, none of which were found. The coordinator, as such, laid the foundation for the examiners to engage with the students' work via the liberties he took with humiliating them, and because no one objected, the Black students continued with the process, with the discomfort that was evidenced by their distraught faces. It is easy to observe how a Black student of architecture in South Africa reflects on issues 
of identity when there is a system of European White domination still prevalent in the country in general and in the programme of Architecture at UKZN in particular. As per Lewis Gordon's article, 'Thoughts on Decolonization',

it does not take much to realize that almost exclusively arguing against Eurocentrism through discussing European thinkers results in maintaining European thought as the center of thought (Gordon 2019).

Some of the students carried the humiliation as though it was a form of punishment for skipping class when the latter was mentioned as part of the introduction of the said student and the work that they produced. In some cases, the remarks were made when a student at the beginning of their presentation that the coordinator had not seen that student for regular classes during the semester; the student was now suddenly presenting the final project without the coordinator's knowledge of a proper progress report or knowledge that the student in question had produced the design under evaluation. The coordinator's comments portrayed the Black students as negligible, irresponsible and untrustworthy. This alone gave examiners a biased approach towards the Black students as no one was aware of the intricacies of the students' attendance before the final examination, except for the coordinator.

What was difficult then, and remains difficult to this day, is understanding the attitudes of superiority of African architects from outside of South Africa (Cote d' Ivoire [the coordinator], Kenya [two examiners] and Uganda [one examiner], where the study and practices of architecture have a long history), towards Black South African students and observing the degree to which Black South African students were put down by these examiners, much like what one observes from resident British colonials. It is not a secret that the Zulu nation has its history within KwaZulu-Natal of fighting the British. It is not a secret either that Black students in South Africa were only able to study Architecture at universities after 1994, which took more than a decade to setup at a great many universities in South Africa. Reddy (2004) At UKZN, the discipline of Architecture opened its doors to black students after 2004. With a history of decolonisation that was known in Kenya, which can be credited to the Mau Mau rebellion of 1952 which lasted for eight years, and a decade later the work of Ngũgĩ wa Thiong'o's (1992) Decolonising the Mind, one would have expected that university-educated Kenyan examiners who spearheaded the humiliation, would show an awareness of the history of exclusion of Black 
students from the discipline of Architecture in South Africa, and not brutalise Black students, by showing them and everyone that they preferred White students. Ngũgĩ wa Thiong'o addresses the issue of African realities that are affected by the greater struggle between the two mutually opposed forces in Africa: an imperialist tradition on the one hand, and a resistance tradition on the other (wa Thiong'o 1992). Memmi, in a similar vein talks about the two options left to the colonised, in The Coloniser and the Colonised:

The first attempt of the colonized is to change his condition by changing his skin. There is a tempting model very close at hand - the colonizer. The latter suffers from none of his deficiencies, has all rights, enjoys every possession and benefits from every prestige. $\mathrm{He}$ is, moreover, the other part of the comparison, the one that crushes the colonized and keeps him in servitude. The first ambition of the colonized is to become equal to that splendid model and to resemble him to the point of disappearing in him (Memmi 1965: 164).

Ngũgĩ's dichotomy and Memmi's psychological critique of internalised colonisation, quoted above, is drawn upon when higher-ranking colonised people crush those they believed to be lower-ranking; the higher ranking colonised people, by inflicting the humiliation, show their admiration for the coloniser in repeating the pattern of abuse and continuing the legacy of the coloniser for all the colonials to see, as was demonstrated in the scenarios I noted above, and for which they were rewarded. The colonised is often rewarded when we show the extent of our colonisation and our willingness to subject other colonised people to servitude. Memmi's extensive work on the process of internalisation that the colonised takes up, suggests that African examiners could have done that precisely when confronted with a situation where Black students, White students and White examiners in the same room aroused old colonial sentiments. The African examiners then, in asserting an imitation of British power over the Black South African students (especially in KwaZulu-Natal) with whom the Kenyan and Ugandan examiners share a coloniser, were as such exercising their prowess and chastising the lower-ranking colonised to assert power and control over the discipline of Architecture. These acts, for the most part, were not verbal but they were present in ways that one experiences with the coloniser who ignores, shuns, 'invisibilises' and as such punishes the colonised insinuating, 'you don't matter... I don't see you'. 
What I am referring to here are acts of non-verbal communication, averted eye contact with Black students, bodily gestures of dismissal, a tone of voice that is suggestive of the British colonisers who colonised Kenyans and South Africans, and to which these Black South Africans students were subjected to in a manner reminiscent of what I had experienced as a learner at a British school in Colombia, and as a university student in the UK.

Whilst I am careful of the insinuation of the colonised extending the arm of colonialism towards the colonised in another location, this component of transference in the Freudian sense, and the colonised who becomes the coloniser in the Albert Memmi sense, cannot go unnoticed. What needs to be stated is: that within the context of a university degree course such as architectture, with examiners coming from East Africa, Uganda and Kenya in particular, anti-colonial struggles as spearheaded by the writing of wa Thiong'o's Decolonising the Mind (1992) and Walter Rodney's How Europe Underdeveloped Africa (1992), played an enormous role in the process of conscientisation of the masses that led to decolonisation, decades ahead of South Africa. One then asks the question of the said examiners who ventured to South Africa to examine the work of Black students from the KwaZulu-Natal region who entered the study of Architecture one decade after democracy was declared: why reproduce the rotten British master and slave paradigm within another African region, when you fought so hard to rid yourself of it? Another question that I had at the time was how it was possible to transition from colonialism to anti-colonialism and then inflict a similar pattern of master-slave dehumanisation against Black students in another region? Transformation Charters were introduced at UKZN after 2008 (and around the country) and the external examiners surely must have been familiar with this. However, it seemed that inflicting superiority and ownership of a field such as architecture was considered a justifiable action - against students whose discipline towards their work and practice as apprentices these examiners were unfamiliar. Nonetheless they inflicted the worst kind of servitude; was this because it was the best demonstration of how they could show that they had become their coloniser?

'The theatre of cruelty', reminiscent of Rozena Maart's article on Marikana stuck in my mind years after this examination process, when I became familiar with the concept she introduced in unpacking the massacre against Lonmin mineworkers inflicted by the South African police (Maart $2014 b$ ). Whilst the acts of cruelty were visible to me they were not always verbal, but disguised in some places to suggest that they were acts that 
belonged to the process of examination and necessary, crucial, to teach students a lesson. These silent acts of racism are reflected by Maart in another article (2014a) who suggests that 'racism in the form of the trace, the hint, the gesture, the murmur - are all acts of atrocities' (Maart 2014a: 55).

The three East African examiners were quick to point out all sorts of deficiencies concerning to the work of Black students, even if a project was competent; they were unkind when delivering their comments (both in the manner and in content), in fact, they were brutal and inflicted the highest form of public humiliation possible. When the White students were introduced by the coordinator and sometimes that introduction was not kind, although nothing close to the humiliation metered against Black students, the three East African examiners in question would compliment the White students even if the project was weak and did not deserve any accolades. Brutality and cruelty are the best descriptions of the acts and series of interactions between these examiners as the perpetrators and the Black students as the victims. Such levels of verbal, and non-verbal brutality were never extended to White students under any circumstances, even when the work was poor. The negative remarks towards South African Black students and general positive remarks towards White students were reflected in the mark allocation of all the students, and it was as clear as daylight that the Black South African students were punished that day - for which crime, I am still uncertain.

Knowledge production within Architecture is still reflected by the standards that were set up by the colonial and apartheid legacy. It is this in-theflesh presence, the agency, the person as subject and actor, reproducing the act of coloniality that was perhaps the most disturbing. As Maart notes: '... agency is key to the formation of knowledge production ...' (Maart 2014a: 56) and the East African examiners used their agency to frequently comment negatively on the work of the Black students and rarely on the work of the white students. In doing so, they asserted their willingness to side with and participate on the side of the White colonials, in showing Black students that they have risen above their colonised status and have become, even momentarily, the new coloniser. Not only did the East African examiners identify with the White lecturers, and locked gazes with them to show silent, unspoken solidarity of the maintenance of Black debasement, they showed a particular form of exceptionalism, one I would paraphrase as follows: we are the better Africans and look down on the Zulu newcomers to architecture - we are also the better Blacks, the more esteemed ones, and we learnt very well from our British colonisers! 


\section{Looking for Reason}

Over the years when confronted with a situation where power was exerted and debasement was the objective, I found myself wondering why it happened. It is both difficult and troubling to understand why both the fifth year coordinator and the three East African examiners presented their display of seeking affinity with White students, praising their work, even if the work was mediocre and in stark contrast to how they behaved when a Black student was introduced. There was no exception for this behaviour throughout the presentation process. What this attitude of debasement sought to show, is that the British colonisers were correct in their assertion that the 'native needed discipline and cannot prosper' until as the colonised he transgresses and becomes the British coloniser, he is at his best. Lester (2001) Not only is he at his best because he values and shows the behaviour of his master, but he ensures that those over whom he presides, those he dominates understand it too and suffers through it in the same way. Why would the high-ranking colonised show the coloniser that he was relevant in his life? As a fair-skinned Latino man I found the behaviour of the fifth-year coordinator and the three examiners embarrassing. Their behaviour was transparent to me. If I could see it, be witness to it, surely the White colonials in the room could see the blatant attempt at reproducing coloniality - or so I thought? But I was wrong. As a newcomer, I found myself at a loss for words at the time. The scenarios never left my mind as I replayed them over and over in my mind.

\section{Curriculum}

Architecture at UKZN has been taught over the years from an exclusively Eurocentric curriculum that focused on the historical, technological, and ideological points of interest. The university in question: the University of KwaZulu-Natal, was called the University of Natal, part of the apartheid education system of White-only universities. When the University of Natal merged with the University of Durban, Westville, the advent of transformation began with an emphasis of opening the doors to Black and Indian students. Despite this grand gesture, the Eurocentric curriculum remained intact, held together by the glue of White privilege and false colonial superiority, and Black liberalism by those who still come across as though they are so happy to work at a university under the leadership of White colonials or African liberals who look down their noses at African systems of knowledge. As such, despite 
UKZN's claims of transformation and diversity, very few efforts have been made to transform the way that students learn in architecture as well as what they learn. George Yancy discusses issues of diversity as simply talk, nothing more. He notes:

if diversity-talk is to be more robust, and if diversity at the level of lived experience is to be more fruitful and vivacious, then it is necessary that we engage in the process of un-concealing Whiteness revealing the subtle dynamism as destructive (Yancy 2012: 44).

The reality at UKZN is fitting and speaks directly to what Yancy directs our attention. Owen digs a little deeper, explaining that with,

recent South African Architecture, one often experiences a deeply disturbing ambivalence: an oscillation between admiration for its intelligence, formed experimentation and audacity, and for the frequency with which such work has been realized: and revulsion at the social context within which it has been produced (Owen 1989: 3).

Owen's assertion speaks directly to the matter of the curriculum, which has not been addressed despite the constant reminder that we live in a democracy.

Even in 2020, Architecture at UKZN teaches our students a European understanding of architecture as though it is the pinnacle of academic acceptance. Post-2004, Architecture at UKZN still had a high percentage of White students. These days, especially post 2011, Black and Indian students form the majority, yet there is no reference to the Black South African or South African Indian built environment, both historically and within the contemporary setting, that allows them to be explored and to be treated as academically relevant and necessary. Maart makes a point in her work to address the question of attitude, especially because the UKZN Transformation Charter references and openly declares the history of apartheid at the start of the said document. Maart notes, that despite this revelation, '[h]owever, I contend that whilst one can legislate for, and against, almost anything and everything one cannot legislate attitude!' (Maart 2014a: 57). This is still prevalent concerning the curriculum that is taught in Architecture at UKZN, where Black staff fear that they will be looked down upon for suggesting that more African content is needed, some of whom have little knowledge of 
African architecture because they have never been taught it. Therefore, they become actors, carriers of Eurocentric knowledge systems, reproducing the same colonial framework among the Black students they teach.

This article would not be complete without referencing the operation of Afrikaans nationalism amid the quest for transformation and within the current context of decolonisation. In 2017, Professor Ora Joubert asked several colleagues (myself included) to provide the name of the top Masters' student at UKZN. Those of us who were consulted on the matter believed that only one student, a young Black man, carried enough prestige to hold such a title: not only did he have a talent for thinking beyond his years, but also because he had the best hand drawings that I have seen in my almost ten years at UKZN. The objective was to include the student's work in a collection Joubert (2017) edited, 10 years +100 projects: Architecture in a Democratic South Africa. When the editor made her final decision, it was a big surprise to us to find that the young Black man we had put forward was not even on her list. Instead, it was an undergraduate White Afrikaner who completed his Masters' degree at the University of the Free State but now listed under the UKZN section. The quality of his work was not even close to that of the young Black student we had put forward for consideration. Besides, there were other students at UKZN whose work was more deserving than the White student in question. The process of democracy that is claimed in the title of the work was never extended to the Black student; the editor's choice was seemingly based on the fact that she chose an Afrikaner student, in line with her own identity, enforcing Afrikaner nationalism and did not show the slightest concern for democracy, while ready to utilise the phrase in the title that stood in stark contrast to her political practice.

Drawing on Manning's reflection that 'Apartheid social engineering used the Built Environment as part of its repressive arsenal against Black South Africans' (Manning 2004: 5) it is easy to illustrate how a White architect would still prefer to showcase the work of a White student rather than that of a Black student. Joubert's choices, made as an Afrikaner nationalist, uses the term 'democracy' in her title. But where was the democracy that she claimed to exercise? She uses a South African history of apartheid, the heralding of a new democracy, which makes her a heroine because she is utilising political phrasing that situates her at the forefront of a process of which she is not a part. She is in fact only utilising the words and the phrases, while actively practising racism as an Afrikaner nationalist. 
When I participated as an external examiner at Nelson Mandela University, Port Elizabeth in 2019, the examination was done in two panels. In two days, we were presented with the students in our panel. After two days of examination and marking, all examiners got together and together where we were shown both student panels. The examination committee consisted of two Black architects, seven White architects, and me, thus making ten panel members.

Two students, one from each panel, got the same mark, which was the highest. One in our panel was an Indian student from Mauritius who presented a beautiful project with exquisite drawings and most importantly he presented the full extent of his process during the semester of how much he had thought out, mapped out, and contemplated his project with different approaches, clearly not satisfied with an initial attempt at his design but with major thought processes of inquiry that was simply commendable.

The other student on the second panel was an Afrikaner male who presented an interesting project of a sheep farm revitalization in the interior of the Eastern Cape. It was also a very well developed and competent project. To select the top student then became the focus of our task. This student would also represent the university at a national competition. Here, once again, the principle of democracy was exercised. To me, it was a 'no-brainer' that the White panellists all voted for the White student without fail, which meant that a 7 to 3 vote was never going to give the Indian student from Mauritius a chance at experiencing democracy nor be rewarded fairly for his work. Unfortunately, I was right.

Manning has written on how the general impact of architecture is viewed in South Africa. Manning notes: 'an architecture that is both in tune with African culture, and celebratory of African cultural heritage rather than that of European needs' (Manning 2007: 10) reflects on the need to 're-evaluate how architecture must be seen removing European White supremacists' standards'. It is accurate indeed to say that the White supremacists' attitudes, social practices and political gestures that were rife during the apartheid years are still very much intact.

\section{Conclusion}

In this article, I have offered an indication of how examiners from other parts of the African continent come into a university in KwaZulu-Natal and assert a hierarchical position of power over Black students of Zulu heritage as a means 
to show that they have been working in the field of architecture longer than the previously disadvantaged students, who are trying to enter the field. I have also illustrated how internalised colonisation on the part of the colonised does not necessarily produce actors who continue their future in freedom. Actors who act to reproduce colonisation do so because they want the same rewards they believe their colonisers received. Many a time, people who reproduce these patterns believe that they have an audience and that particular audience was the White students, however few White people were in the room was of no significance. It was a means of saying to the White people who were present: 'look, we are just like you, we are like our White coloniser'.

Observing this display of glorification of the coloniser, being the colonised, inflicting hurt and harm, was both frustrating and embarrassing because I saw the examiners as making fools of themselves and demeaning certain students. By all accounts, they did not care what I thought because they were not there to impress me. It is important to recognise that just because people go through a process of anti-colonial struggles does not make them free from reproducing power dynamics in other places, continuing to use racialisation and/or ethnic hierarchies as a basis to stage forms of power. The editor of the book and the choices she made as an Afrikaner nationalist while using the title of democracy is just as much a mockery as the East African examiner who asserts a false identity and imitates the coloniser so that he (and they) can feel powerful, and masterful. Where was the democracy that she should have exercised in giving the young Black man the credit he deserves? One could say she is using the South African history of apartheid, the heralding of a new democracy which makes her a heroine (in her eyes) because she is utilising political phrasing that situates her at the forefront of a process of which she is not part. In fact, it would seem she is only utilising the words and the phrases but is still basically practising the racism and Afrikaner nationalism to uphold racism.

Acknowledgement: Juan I. Solis-Arias wishes to acknowledge the National Research Foundation of South Africa (NRF), for their support through the research grant, 'Critical Times, Critical Race', and the national Institute of the Human and Social Sciences (NIHSS) for their support through the research grant, 'Race, Space and the City'. 


\section{References}

Coetzer, N. 2016. Building Apartheid: On Architecture and Order in Imperial Cape Town. London and New York: Routledge.

Dodson, B. 2013. Reconfiguring Space, Reimagining Place: Post-apartheid Geographies of South Africa and its Region. The Canadian Journal of African Studies 47,1:1ff.

Gordon, L. 2020. Some Thoughts on Decolonization, Decoloniality, Racism, and Challenges of Citizenship in Communities of Learning. Alternation Special Edition 33: $60-86$.

http://alternation.ukzn.ac.za/Files/articles/special-editions/33/03gordon.pdf

Kallaway, P. (ed.). 2002. The History of Education Under Apartheid, 19481994: The Doors of Learning and Culture Shall be Opened. South Africa: Pearson Education.

Joubert, O. (ed.). 2017. 10 years +100 Projects: Architecture in a Democratic South Africa. Cape Town: Bell-Roberts Publishing.

Lester, A. 2001. Imperial Networks Creating Identity in Nineteenth-century South Africa and Britain. London and New York: Routledge.

Maart, R. 2014a. When Black Consciousness Walks Arm-in-arm with Critical Race Theory to Meet Racism and White Consciousness in the Humanities. Alternation 21,2: 54-82.

http://alternation.ukzn.ac.za/Files/docs/21.2/04\%20Maa.pdf

Maart, R. 2014b. Philosophy Born of Massacres. Marikana, the Theatre of Cruelty: The Killing of the 'Kaffir'. Acta Academia 46,4: 1 - 28. https://journals.ufs.ac.za/index.php/aa/article/view/1470/1447

Manning, J. 2004. Racism in Three Dimensions: South African Architecture and the Ideology of White Supremacy. Social Identities 4 - 10.

Memmi, A. 1965. The Colonizer and the Colonized. Boston: Beacon Press.

Ministerio de Educacion 2011 Revista Colombiana de Antropologia.

Netswera F.G. \& N. Mathaba 2006. A Pervasive Apartheid? An Analysis of Changing Higher Education in South Africa and its Relationship with the State. Journal of Educational Administration and History 38.

wa Thiong'o, N. 1992. Decolonising the Mind. Nairobi, Kenya: East African Educational Publishers.

O'Connell, S. 2014. The Aftermath of Oppression: In Search of Resolution through Family Photographs of the Forcibly Removed of District Six, Cape Town. Social Dynamics, A Journal of African Studies 40. 
Owen, G. 1989. Forget Europe, Forget America: Architecture and Apartheid. Journal of Architectural Education 42, 3, Spring: 3 - 23.

Reddy, T. 2004. Higher Education and Social Transformation: South African Case Study. Pretoria: Council on Higher Education.

Rodney, W. [1972] 2018. How Europe Underdeveloped Africa. London, New York: Verso.

Yancy, G. 2012. How Can You Teach Me if You Don't Know Me? Embedded Racism and White Opacity. Philosophy of Education 44 - 54.

Juan Ignacio Solis-Arias

Lecturer in Architecture University of KwaZulu-Natal Durban, South Africa solis@ukzn.ac.za 